\title{
ASSESSMENT OF MAGNESIUM STATUS IN TYPE 2 DIABETES MELLITUS
}

\author{
Sangeeta Singh ${ }^{1}$, Neetu Arora², Seema Shah³, Vivek Sharma ${ }^{4}$, Vijay Shankar ${ }^{5}$ \\ ${ }^{1}$ Associate Professor, Department of Biochemistry, SHKM, Government Medical College, Nalhar, Nuh, Mewat, Haryana. \\ ${ }^{2}$ Associate Professor, Department of Anatomy, SHKM, Government Medical College, Nalhar, Nuh, Mewat, Haryana. \\ ${ }^{3}$ Associate Professor, Department of Biochemistry, SHKM, Government Medical College, Nalhar, Nuh, Mewat, Haryana. \\ ${ }^{4}$ Demonstrator, Department of Biochemistry, SHKM, Government Medical College, Nalhar, Nuh, Mewat, Haryana. \\ 5 Professor, Department of Biochemistry, SHKM, Government Medical College, Nalhar, Nuh, Mewat, Haryana.
}

ABSTRACT

\section{BACKGROUND}

Global burden of type $2 \mathrm{DM}$ is raising. The condition is characterized by established decreased insulin secretion and insulin action. Many factors are responsible for this. Magnesium deficiency is commonly reported in type 2 DM. Decreased magnesium level may worsen insulin sensitivity and insulin action. Routinely, this biochemical alteration in type 2 diabetes is not addressed by the physicians.

\section{AIM OF THE STUDY}

To evaluate the levels of serum magnesium in patients of type 2 DM visiting our hospital to highlight this issue in our population.

\section{MATERIALS AND METHODS}

The study was conducted on 50 patients of type $2 \mathrm{DM}$ and 50 healthy controls who were age and sex matched. Fasting blood sugar and serum magnesium were estimated by fully automatic analyzer in all the subjects.

\section{RESULTS}

The level of serum magnesium in type 2 diabetes were found to be decreased as compared to control and the results were compared and analysed by student's ' $t$ ' test. The difference was significant.

\section{CONCLUSION}

In this study, we found serum magnesium level of type 2 diabetics significantly lower than healthy control subjects $(\mathrm{P}<0.001)$. Low magnesium levels may be the risk factor for the associated increased inflammation, oxidative stress, hypercoagulability and dyslipidemia in type 2 diabetes. Magnesium supplementation or dietary intake of magnesium rich food is beneficial to avoid and delay complication of type $2 \mathrm{DM}$.

\section{KEYWORDS}

Magnesium, Type 2 DM, Hypomagnesaemia.

HOW TO CITE THIS ARTICLE: Singh S, Arora N, Shah S, et al. Assessment of magnesium status in type 2 diabetes mellitus. J. Evolution Med. Dent. Sci. 2016;5(17):864-866, DOI: 10.14260/jemds/2016/199

\section{INTRODUCTION}

Type $2 \mathrm{DM}$ is a lifelong disease. India leads the world in its largest number of diabetes subjects as compared with other given country. It has been estimated that presently 19.4 million individuals are affected by diabetes and the numbers are expected to increase to 57.2 million by the year $2025\left(1 / 6^{\text {th }}\right.$ of world total).(1)

According to the results of many longitudinal and crosssectional studies, it has been demonstrated that the earliest detectable abnormality in NIDDM is impairment in body ability to respond to insulin.(2) The metabolic disorder is characterized by abnormal hyperglycemia with disturbance of carbohydrate, fat and protein metabolism which result from defects in insulin secretion, insulin action or both. An alteration in the metabolism of minerals was demonstrated in many cases of diabetes. $(3,4,5)$

Financial or Other, Competing Interest: None.

Submission 06-01-2016, Peer Review 06-02-2016,

Acceptance 12-02-2016, Published 29-02-2016.

Corresponding Author

Dr. Neetu Arora,

D-5/11, Ground Floor, Ardee City,

Sector-52, Gurgaon-122011.

E-mail: drneetuarora@gmail.com

DOI: $10.14260 /$ jemds/2016/199
In human, diabetes causes disturbances in the magnesium metabolism. Magnesium has an important role in phosphorylation reaction of glucose and its metabolism. Its deficiency has been implicated in insulin resistance, carbohydrate intolerance, dyslipidemia, etc. It is generally believed that a strict metabolism control delays the development of diabetes mellitus.(6) Magnesium depletion has a negative impact on glucose homeostasis and insulin sensitivity in patients with type 2 DM. Magnesium depletion has been linked to the development of retinopathy thrombosis and hypertension..$^{(7,8,9)}$

Magnesium intake was inversely associated with incidence of diabetes in young American adults.(10) Clinically, hypomagnesaemia may be defined as serum $\mathrm{Mg}^{++}$ concentration $<1.6 \mathrm{mg} / \mathrm{dL}$ or $\mathrm{SD} \pm 2$ below the mean of the general population, which can be corrected by magnesium supplements.(11,12) Hence in this study, we evaluated serum magnesium in type 2 diabetes to know the magnesium status of these patients visiting to SHKM Govt. Medical College.

\section{MATERIALS AND METHODS}

The study was approved by the Institutional Ethics Committee. A written informed consent was obtained from all participants in this study. 
A total of 50 patients with type 2 diabetes mellitus, who attended medicine department in SHKM Govt. Medical College were recruited during year 2014-15. The diagnosis of type 2 diabetes mellitus was confirmed by biochemical investigations as per WHO criteria.(13) Fifty age and sex matched apparently healthy individuals with normal plasma glucose and with no symptoms suggestive of DM were taken as controls in this study.

They were divided into two groups.

Group I- Type 2 diabetes mellitus patients (Diagnosed on the basis of biochemical investigation as per WHO criteria) with normal renal function were included. Group II- Control group which comprised of healthy individuals who had normal blood glucose level and also had normal renal function.

\section{Exclusion Criteria}

The patients with acute and chronic diarrhoea/malabsorption states with thyroid and adrenal dysfunction, history of alcohol intake, history of vitamin or mineral supplements in the recent past, recent metabolic acidosis, pregnancy, lactation with serum creatinine $\geq 1.5 \mathrm{mg} / \mathrm{dL}$ and on drugs known to affect magnesium levels were excluded from the study.

Fasting venous blood samples were collected from cases and controls and the samples were centrifuged, serum was separated and stored at 40C. Fasting plasma glucose was estimated by using commercially available kit in automated analyzer. Fully automatic analyzer "Roche Evo 500" was used for serum magnesium measurement. For serum magnesium evaluation, Magnesium Xylidyl Blue Method which is based on Serum Magnesium ions reaction with Xylidyl Blue in an alkaline solution to produce a red complex that is measured spectrophotometrically.(14) The intensity of color produced is directly proportional to magnesium concentration. Calcium interference is virtually eliminated by the use of EGTA and a surfactant system is included to remove protein interference.

\section{Statistical Analysis}

The Statistical software SPSS 15.0 was used for the analysis of the data and Microsoft Excel have been used to generate graphs and tables. Chi square test and Student ' $t$ ' test have been used to find the significance of study parameters between two groups of subjects. Results were expressed as mean+SD. Probability values of $\mathrm{P}<0.05$ were considered to indicate statistical significance.

\section{RESULTS}

The comparative controlled study consisting of 50 diabetics without any complications and 50 non-diabetic healthy subjects were taken to investigate the pattern of serum magnesium in the mentioned groups. The average age of the subjects in the control group was $52 \pm 11.46$, while in experimental group (Group I) was $54 \pm 10.06$ (Table 1). Among all the groups the gender distribution was of the same, i.e. $50 \%$ and $50 \%$ males and females respectively. The average range of FBS in diabetic was $153.46 \pm 22.49 \mathrm{mg} / \mathrm{dL}$. The mean levels healthy subjects were $79.63 \pm 5.85 \mathrm{mg} / \mathrm{dL}$ (Table 2). The difference was statistically significant ( $\mathrm{P}$ value $<0.001$ ).

There is significant difference between levels of serum magnesium levels among diabetics and healthy subjects. The mean serum magnesium levels among the group I was $1.46 \pm 0.23 \mathrm{mg} / \mathrm{dL}$, while in group II was $2.02 \pm 0.21 \mathrm{mg} / \mathrm{dL}$ respectively $(\mathrm{p}<0.001)$ (Table 2$)$. The serum magnesium level was lower in the type 2 diabetic than healthy subjects (Fig. 1).

\section{DISCUSSION}

Reduced magnesium level may be the result of enhanced renal magnesium excretion. Insulin has been related to magnesium reabsorption at the thick ascending loop of Henle. Insulin deficiency or resistance can promote magnesium wasting at this nephron segment. ${ }^{(8,15)}$ Insulin seems to be one of the most important factors that regulate plasma and intracellular magnesium concentration. It has been suggested that ATPase dependent pump is involved in the mechanism by which insulin regulates erythrocyte magnesium content.(16) In states of insulin resistance, insulin induced entry of magnesium is impaired into the cells.

Available data suggests that low $\mathrm{Mg}^{++}$level may promote endothelial cell dysfunction and thrombogenesis by increasing platelet aggregation and vascular calcification.(17) Low circulating magnesium levels have been related to elevated blood pressure, atherogenic dyslipidemia, impaired clotting, increased inflammatory burden, oxidative stress, carotid wall thickness and coronary heart disease. ${ }^{(18,19)}$

Decreased magnesium level is a risk factor and favours diabetic complications. Magnesium replacement by promoting dietary replacement and with nutritional medicinal supplements may be a healthy lifestyle to delay the onset of diabetes and its complications.

In this study, we found serum magnesium level of type 2 diabetics significantly lower than healthy control subjects $(\mathrm{P}<0.001)$. Low serum magnesium in type $2 \mathrm{DM}$ were also reported in previous studies. $(16,20,21)$

\section{CONCLUSIONS}

In this study, we found serum magnesium level of type 2 diabetics significantly lower than healthy control subjects $(\mathrm{P}<0.001)$. Low magnesium levels may be the risk factor for the associated increased inflammation, oxidative stress, hypercoagulability and dyslipidemia in type 2 diabetes. The estimation of serum magnesium levels is helpful to monitor the severity of complications in type 2 diabetes and also be useful for proper medical intervention. Magnesium supplementation or dietary intake of magnesium rich food is beneficial to avoid and delay complication of type $2 \mathrm{DM}$.

\begin{tabular}{|c|c|c|c|c|}
\hline Group & Number & $\begin{array}{c}\text { Age } \\
\text { (Mean } \pm \\
\text { SD) }\end{array}$ & Male & Female \\
\hline $\begin{array}{c}\text { Group I } \\
\text { (Diabetics) }\end{array}$ & 50 & $54 \pm 10.6$ & 25 & 25 \\
\hline $\begin{array}{c}\text { Group II } \\
\text { (Control) }\end{array}$ & 50 & $52 \pm 11.46$ & 25 & 25 \\
\hline \multicolumn{4}{|c|}{ Distribution of the Study Population } \\
\hline
\end{tabular}

\begin{tabular}{|c|c|c|c|c|}
\hline & N & Control & Diabetics & P value \\
\hline FBS (mg/dL) & 50 & $\begin{array}{c}79.54 \pm \\
5.88\end{array}$ & $\begin{array}{c}153.46 \pm \\
22.49\end{array}$ & $<0.001$ \\
\hline Serum Mg & 50 & $2.02 \pm 0.21$ & $1.46 \pm 0.23$ & $<0.001$ \\
\hline Table 2: Comparison of FBS \& Serum Magnesium \\
Level in Diabetic Patients was Significantly \\
Lower (P<0.001) than the Control \\
\hline
\end{tabular}




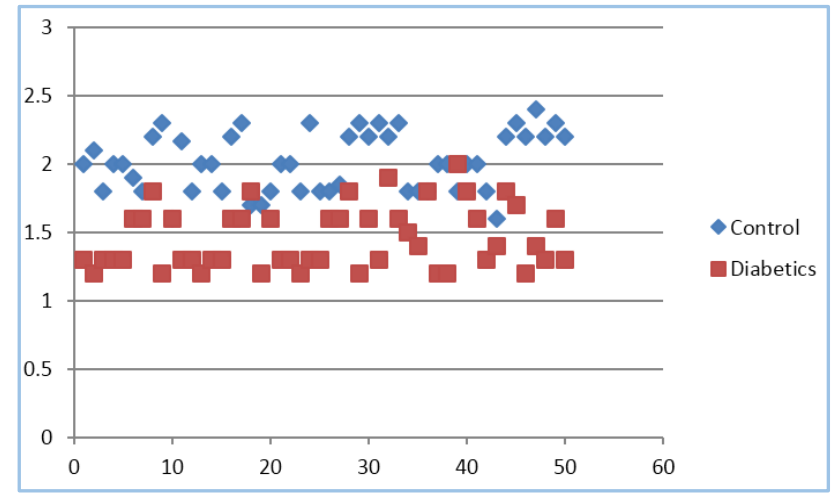

Fig. 1: Scatter Chart showing Frequency of Distribution of Magnesium among Control and Diabetics

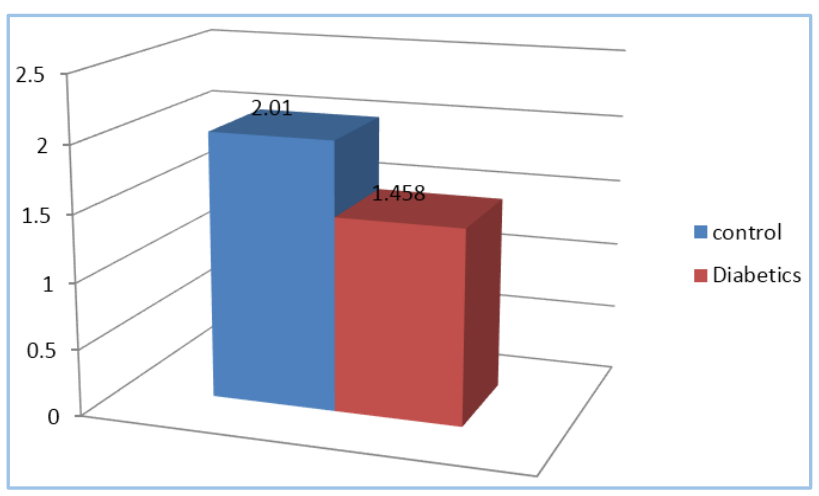

Fig. 2: Showing Serum Magnesium Level in Two Groups

\section{REFERENCES}

1. King H, Aubert RE, Herman WH. Global burden of diabetes, prevalence, numerical estimates and projections. Diabetes Care 1998;21(9):1414-31.

2. De Fronzo RA, Bonadonna RC, Ferrannini E. Pathogenesis of NIDDM. A balanced overview. Diabetes Care 1992;15(3):3138-68.

3. Chausmer AB. Zinc, insulin and diabetes. J AM Coll Nutr 1998;17(2):109-15.

4. Forrst H Nielson. New essential trace elements for the life sciences. Biol Trace Elem Res 1990;26-27:599-611.

5. Resnick LM, Gupta RK, Bhargava KK, et al. Magnesium deficiency in diabetes. Hypertension 1991;17:951-57.

6. Cahill GF, Elzwiler DD, Freinkel N. Control and Diabetes. N Engl J Med 1976;294:1004-1005.

7. McNair P, Christiansen C, Madsbad S, et al. Hypomagnesaemia, a risk factor in diabetes retinopathy. Diabetes 1978;27:1075-77.
8. Pham PCT, Pham PMT, Pham SV, et al. Hypomagnesaemia in patient with type 2 diabetes. Clin J Am Soc Nephrol 2007;2:366-73.

9. Kao WH, Folsom AR, Nieto FJ, et al. Serum and dietary magnesium and the risk for type 2 diabetes mellitus: the atherosclerosis risk in communities study. Arch Intern Med 1999 Oct 11;159(18):2151-9.

10. Radia H. Meta-analysis: magnesium intake linked to lower risk of type 2 diabetes. Diabetes care 2011;34(9):2116-22.

11. Durlach J, Bac P, Durlach V, et al. Magnesium status and ageing: an update. Magnes Res 1998 Mar;11(1):25-42.

12. Mooren FC, Krüger K, Völker K, et al. Oral magnesium supplementation reduces insulin resistance in nondiabetic subjects-a double-blind, placebo-controlled, randomized trial. Diabetes Obes Metab 2011;13(3):281-4.

13. World Health Organization. Screening for type 2 diabetes, report of a World Health Organization and International Diabetes Federation meeting Geneva: World Health Organization, 2003

http://www.who.int/diabetes/publications/en/screenin g_mnc03.pdf

14. Abernethy MH, Fowler RT. Micellar improvement of the calmagite compleximetric measurement of magnesium in plasma. Clin Chem 1982;28(3):520-2.

15. Topf JM, Murray PT. Hypomagnesemia and hypermagnesemia. Rev Endocr Metab Disord 2003; 4(2):195-206.

16. Supriya Mohanty S, Pinnelli VB, Murgod R, et al. Evaluation of serum copper, magnesium and glycated haemoglobin in type 2 diabetes mellitus. Asian J Pharm Clin Res 2013; 6:188-90.

17. Paolisso G, Sgambato S, Passariello N, et al. Insulin induces opposite changes in plasma and erythrocyte magnesium concentrations in normal man. Diabetologia 1986;29(9):644-7.

18. Pham PC, Pham PM, Pham PA, et al. Lower serum magnesium level are associated with more rapid decline of renal functions in patients with diabetes mellitus type 2 . Clin Nephrol 2005;63(6):429-36.

19. Ishrat Kareem SA, Jaweed JS, Bardapurkar VP, et al. Study of magnesium, glycosylated hemoglobin and lipid profile in diabetic retinopathy. Indian Journal of Clinical Biochemistry 2004;19(2):124-127.

20. Rasic Milutinovic Z, Perunicic-Pekovic G, Pljesa S, et al. Magnesium deficiency in type 2 diabetes. Hippokratia 2004;8:181.

21. Walti MK, Zimmermann MB, Spinas GA, et al. Low plasma magnesium in type 2 diabetes mellitus. Swiss Med Wkly 2003;133:289-292. 